\title{
Evaluating the Effect of Soil Texture on the Response of Three Types of Sensors Used to Monitor Soil Water Status
}

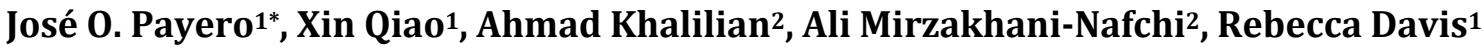 \\ ${ }^{1}$ Edisto Research and Education Center, Clemson University, Blackville, SC, USA \\ ${ }^{2}$ Department of Agricultural Sciences, Clemson University, Clemson, SC, USA \\ Email:`jpayero@clemson.edu,xqiao@g.clemson.edu,akhlln@clemson.edu,anafchi@clemson.edu,rwllms@clemson.edu
}

How to cite this paper: Payero, J.O., Qiao, X., Khalilian, A., Mirzakhani-Nafchi, A. and Davis, R. (2017) Evaluating the Effect of Soil Texture on the Response of Three Types of Sensors Used to Monitor Soil Water Status. Journal of Water Resource and Protection, 9, 566-577.

https://doi.org/10.4236/jwarp.2017.96037

Received: April 10, 2017

Accepted: May 8, 2017

Published: May 11, 2017

Copyright ( 2017 by authors and Scientific Research Publishing Inc. This work is licensed under the Creative Commons Attribution International License (CC BY 4.0).

http://creativecommons.org/licenses/by/4.0/

\section{(c) (i) Open Access}

\begin{abstract}
Accurate monitoring of soil water status can be an important component of precision irrigation water management. A variety of commercial sensors measure soil water status by relating sensor electrical output to soil water content or soil water potential. However, sensor electrical output can also be affected by soil characteristics other than water content, such as soil texture, salinity, and temperature. This makes it difficult to accurately measure and interpret soil water status without prior on-site calibration. In this study, we investigated the impact of soil texture on the response of three types of sensors commonly used to monitor soil water status, including the Decagon EC-5, the Vegetronix VH400, and the Watermark 200ss granular matrix sensor. A replicated laboratory experiment was conducted to evaluate the response of these types of sensors using four major soil textural classes commonly found in South Carolina. We found that the three types of sensors had a significant response to changes in soil water content, but while the EC-5 and VH400 sensors had a linear response, the Watermark 200ss had a curvilinear response that was explained by an exponential decay function. The response of the three sensor types, however, was significantly affected by soil texture, which will significantly affect the trigger point used to initiate irrigation based on the output from these sensors. Therefore, it is suggested that guidelines on how to use these sensors for local soils need to be developed and made available to farmers, so that they can make better irrigation scheduling decisions.
\end{abstract}

\section{Keywords}

Soil Moisture, Soil Texture, Irrigation, Sensors, Calibration, Soil Water

\section{Introduction}

Irrigated acreage in South Carolina has been increasing rapidly in recent years. 
Irrigated acreage doubled from 1997 to 2011, and the adoption of irrigation has accelerated considerably since 2002, increasing at a rate of 9184 acres per year [1]. Since irrigation has been adopted so rapidly in the state, farmers lack experience, information and tools to manage irrigation in a sustainable manner. For example, the 2008 Farm and Ranch Irrigation Survey [1] showed that in South Carolina more than $95 \%$ of growers, which is much higher than the national average of around $80 \%$, reported using "the condition of the crop" as the primary method of determining when to irrigate. This could lead to waste of significant amounts of water, to increased pumping cost, and to environmental degradation caused by over-irrigation. Alternatively, it could also lead to crop stress, reduced crop yields, and lower economic returns caused by under-irrigation.

Previous work has shown that irrigation management using soil moisture sensors can significantly reduce water use while maintaining or increasing yields and profits [2] [3] [4]. However, the wide variety of commercial soil moisture monitoring systems currently available makes it very difficult for farmers to make a good educated decision on which sensor to use and how to interpret the data collected using these sensors to make irrigation scheduling decisions. These soil moisture monitoring systems range from single moisture sensing probes to multiple-depth probes, utilizing a variety of sensing technologies, such as electrical resistance [5] [6], neutron scattering [7], capacitance [8], time domain reflectometry [9] [10], etc. Some sensors are read manually while others include automatic monitoring and telemetry, with data transmitted in real time using radio, satellite or mobile communication technologies. Also, some systems can be set up to automatically trigger irrigations while for most systems, the resulting data need to be interpreted by the user before using the information to manually control the irrigation system. In addition, these systems can vary significantly in cost depending on the type of sensor, the number of sensors, data logging options and data transmission capabilities.

An issue, however, that has traditionally contributed to limiting adoption of soil moisture sensing technologies by farmers is the need to conduct on-site calibration [11] [12] [13]. Most farmers, however, are not likely to conduct on-site sensor calibration since it can be a difficult and time-consuming process. Consequently, there is a need for researchers and sensor distributors to develop guidelines on how to interpret the output of soil moisture sensors for different soil types. Local information is also needed on how to use sensor data to improve irrigation scheduling decisions. The objective of this study was to investigate the impact of soil texture on the response of three types of soil moisture sensors. The overall goal was to use this information to develop local guidelines on how to use these sensors to schedule irrigation in South Carolina.

\section{Methodology}

\subsection{Sensor Types}

Three soil moisture sensor types were used in this study, including the Decagon EC-5 (Decagon Devices, Pulman, WA), the Vegetronix VH400 (Vegetronix, 
Inc., Riverton, UT), and the Watermark 200ss (Irrometer Company, Inc., Riverside, CA) (Figure 1). These sensors were selected for their relatively low cost, which makes them affordable for most growers. Current purchase prices for these sensors are around US $\$ 110$ for the Decagon EC-5, US $\$ 40$ - 56 (depending on cable length) for the Vegetronix VH400, and US $\$ 33$ for the Watermark 200ss.

The Decagon EC-5 sensor determines volumetric water content (VWC) by measuring the dielectric constant of the media using capacitance/frequency domain technology [14]. The sensor manufacturer claims that the $70 \mathrm{MHz}$ frequency of the EC-5 sensor minimizes salinity and textural effects, making it accurate in almost any soil or soilless media. The rated accuracy of the sensor is \pm $3 \%$ VWC in most mineral soils with a salinity level of up to $8 \mathrm{dS} / \mathrm{m}$, and $\pm 1 \%$ $2 \%$ VWC with soil-specific calibration. The rated accuracy is also $\pm 3 \% \mathrm{VWC}$ for rockwool ( 0.5 to $8 \mathrm{dS} / \mathrm{m})$ and potting soil ( 3 to $14 \mathrm{dS} / \mathrm{m})$. The sensor requires an input voltage of 2.5 to $3.6 \mathrm{VDC}$ at $10 \mathrm{~mA}$ and produces an output voltage that is proportional to the soil moisture and to the input voltage. It is designed to operate within the temperature range of $-40^{\circ} \mathrm{C}$ to $+50^{\circ} \mathrm{C}$ and requires a measurement time of $10 \mathrm{~ms}$.

The Vegetronix VH400 sensor measures the dielectric constant of the soil using transmission line techniques [15]. The sensor has an internal voltage regulator and operates with an input voltage of 3.5 to $20 \mathrm{VDV}$, requiring an input current of less than $7 \mathrm{~mA}$. It produces an output voltage in the range of 0 to $3 \mathrm{VDC}$, which can be measured with a regular multi-meter, a data logger, or a microcontroller. The output voltage is related to the water content of the soil. The sensor is also sold as a water level sensor, which explains why it is externally labeled similar to a measuring ruler. The sensor was designed to be insensitive to salinity, operates within the temperature range of $-40^{\circ} \mathrm{C}$ to $+85^{\circ} \mathrm{C}$, and requires a measurement time of $400 \mathrm{~ms}$ after power on to get a stable output.

The Watermark 200ss sensor [16] is a solid-state electrical device that senses electrical resistance and is commonly used to measure soil water potential, rather than soil moisture. The sensor has a pair of corrosion-resistant electrodes in

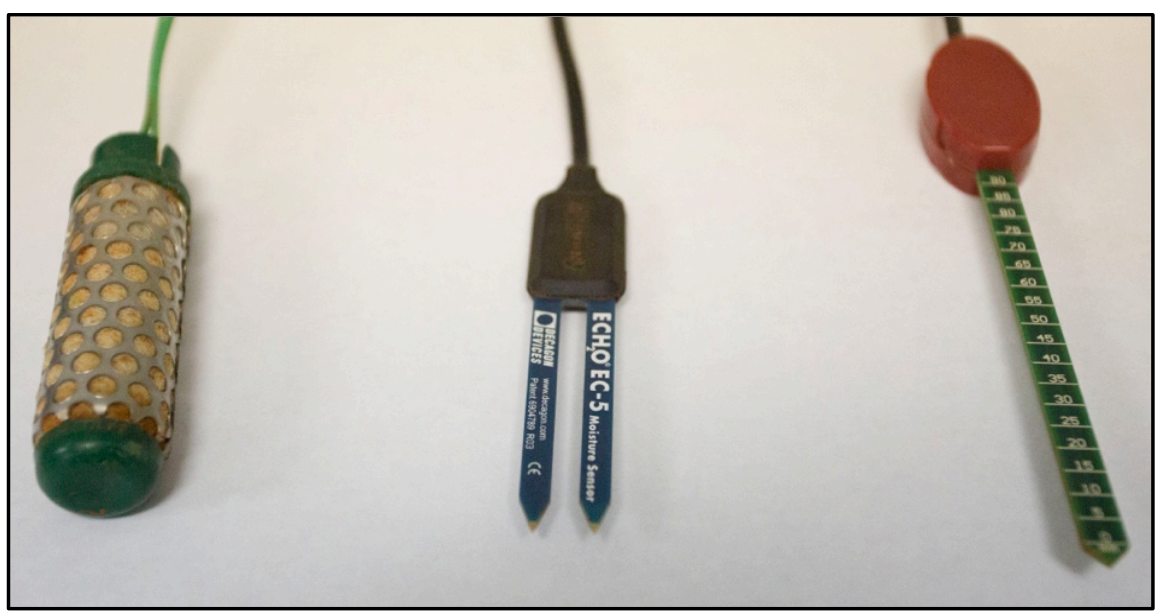

Figure 1. Soil moisture sensors used in the study, including the Watermark 200ss, the Decagon EC-5, and the Vegetronix VH400 (from left to right). 
the shape of two concentric rings. The space between the two rings is filled with a gypsum material to provide a buffer against changes in salinity. The electrodes are imbedded within a granular matrix (a material similar to very fine sand) that creates the bulk of the instrument. The granular matrix is enclosed in two layers, the inner layer is a filter-like material that allows water exchange between the granular matrix and the soil, while the outer layer is a perforated stainless steel frame that provides rigidity and maintains the shape and physical integrity of the sensor. Two ABS plastic green caps are installed at each end of the sensor (Figure 2).

The electrodes are connected to two lead wires (AWG 20) that attach to the data logger. When installed in the soil, water is exchanged between the soil and the granular matrix to reach equilibrium. Since water is an electrical conductor, the resistance between the electrodes decreases as soil moisture increases. The sensor requires application of an electrical current (AC rather than DC) and the output is an electrical resistance (in units of ohm). The electrical resistance correlates to soil water potential (negative pressure), which is usually expressed in units of centibars $(\mathrm{cb})$ or kilopascal $(\mathrm{kPa})(\mathrm{cb}=\mathrm{kPa})$, with a rated range of measurement from 0 to $239 \mathrm{cb}$. Guidelines for using Watermark sensors for irrigation scheduling have been developed by Irmak et al. [17] [18].

In this study, hand-held devices were used to measure the output of the three types of sensors (Figure 3). The output from the EC-5 sensors was measured using a ProCheck sensor readout device (Decagon Devices, Pulman, WA), which outputs the VWC using the factory calibration for mineral soils. The output of the VH400 sensors (in volt) was measured with a FLUKE 117 electrician multi-meter (Fluke Corporation, Everett, WA). The output of the Watermark 200ss sensors (in $\mathrm{cb}$ or $\mathrm{kPa}$ ) was measured using a Watermark Meter (Irrometer Company, Inc., Riverside, CA), which is an alternating current (AC) resistance bridge meter specifically designed to read the Watermark sensors.

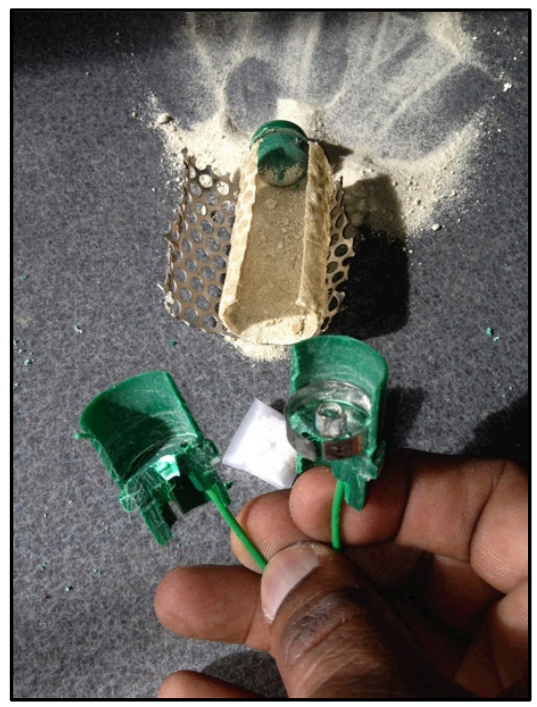

Figure 2. Internal view of the Watermark 200ss sensor. 


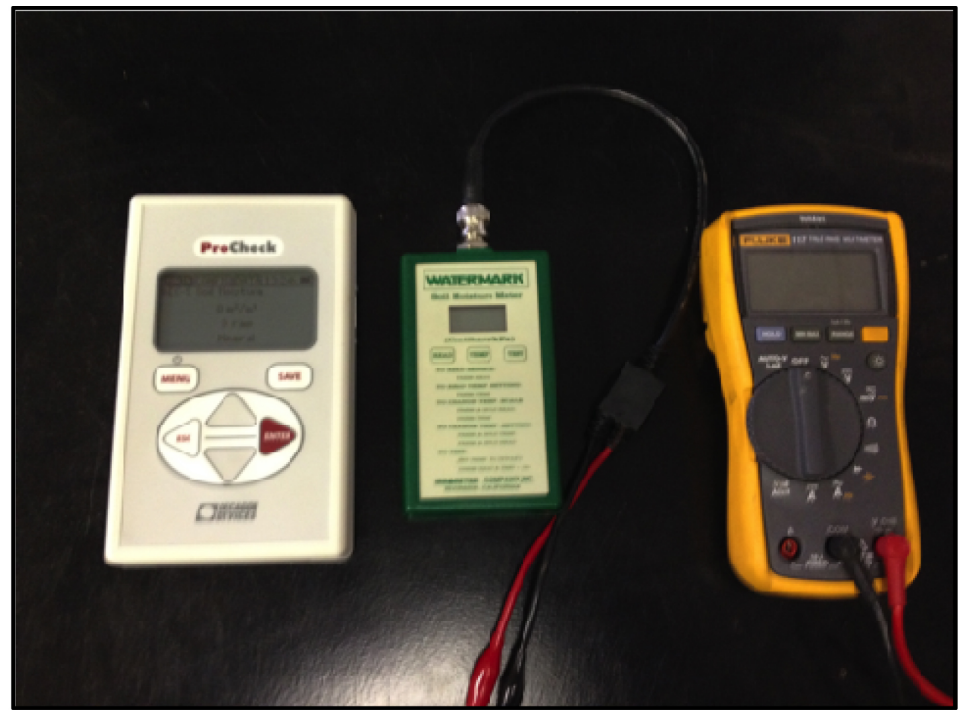

Figure 3. Hand-held devices used to measure the output of the EC-5, Watermark 200ss, and VH400 (from left to right).

\subsection{Soil Textural Classes}

Four soil texture types that are typical of South Carolina farms were used in this study. Physical properties of these soils are shown in Table 1. Soil texture for each soil type was measured in the laboratory using the Hydrometer method [19]. The soil bulk density $(B D)$ was also measured using a disturbed soil sample. Estimates of the volumetric water content (VWC) at field capacity (FC) and permanent wilting point (PWP) were obtained from Saxton and Rawls [20]. The four soil types used in this study all have a high proportion of sand, which is typical of South Carolina soils, and represent the left lower corner of the soil texture triangle (Figure 4).

\subsection{Soil Moisture Measurements}

Before the start of the experiment each soil was oven-dried at $105^{\circ} \mathrm{C}$ for 24 hours using a model 230F IsoTemp oven (Fisher Scientific, Loughborough, UK). Then, for each soil type, three square plastic pots were filled with a $700 \mathrm{~cm}^{3}$ volume $\left(V_{\text {soil }}\right)$ of oven-dried soil. The mass of each pot was measured using a precision laboratory balance with a maximum capacity of $2200 \mathrm{~g}$ and accuracy of $0.01 \mathrm{~g}$ (Kern \& Sohn GmbH, Balingen, Germany). Each pot was placed on top of an aluminum plate and the three sensor types were installed inside each pot (Figure $5)$.

The weight of the container $\left(W_{c}\right)$, the weight of the three sensors $\left(W_{s}\right)$, and the dry weight $\left(W_{d r y}\right)$ of the whole setup (container + dry soil + sensors) were recorded (in grams). The soil was compacted around the sensors to have good contact. After installing the sensors, water was added to wet the soil to field capacity $(F C)$ and the wet weight $\left(W_{\text {wet }}\right)$ (container + wet soil + sensors) was recorded. The amount of water added was estimated by multiplying the $F C$ value by the volume of oven-dried soil $\left(V_{\text {soil }}\right)$. The soil was then allowed to dry at room temperature until the soil was air-dried. During this period, the output of each 
Table 1. Physical properties of each soil type used in the study.

\begin{tabular}{cccccccc}
\hline Soil Texture & $\begin{array}{c}\text { Sand } \\
(\%)\end{array}$ & $\begin{array}{c}\text { Silt } \\
(\%)\end{array}$ & $\begin{array}{c}\text { Clay } \\
(\%)\end{array}$ & $\begin{array}{c}B D \\
\left(\mathrm{~g} \cdot \mathrm{cm}^{-3}\right)\end{array}$ & $\begin{array}{c}F C \\
(\% \mathrm{VWC})\end{array}$ & $\begin{array}{c}P W P \\
(\% \mathrm{VWC})\end{array}$ & $\begin{array}{c}W H C \\
(\% \mathrm{VWC})\end{array}$ \\
\hline Loamy Sand & 86 & 9 & 5 & 1.78 & 12 & 5 & 7 \\
Sandy Clay & 55 & 5 & 40 & 1.43 & 36 & 25 & 11 \\
Sandy Clay Loam & 68 & 8 & 24 & 1.52 & 27 & 17 & 10 \\
Sandy Loam & 68 & 15 & 17 & 1.53 & 18 & 8 & 10 \\
\hline
\end{tabular}

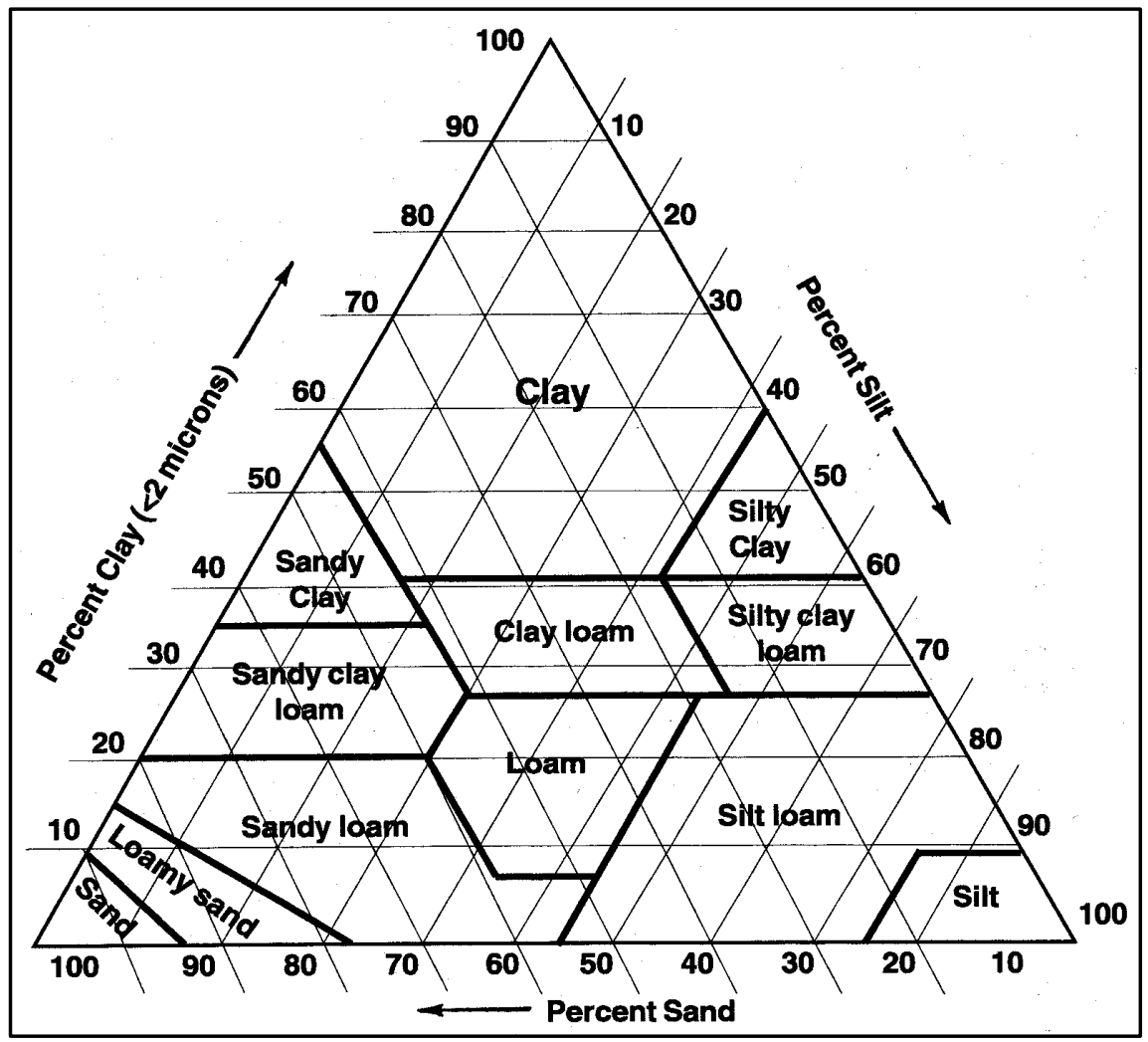

Figure 4. Soil texture triangle.

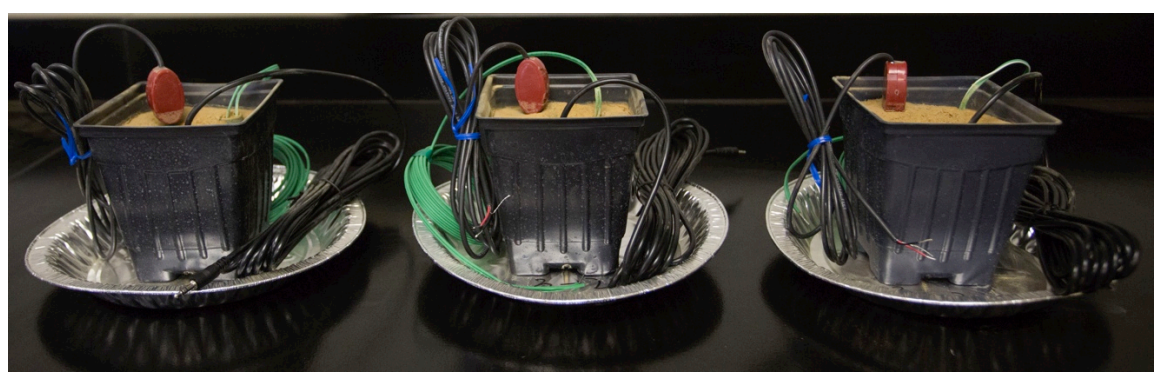

Figure 5. Experiment setup for loamy sand soil.

sensor and the $W_{\text {wet }}$ were recorded once a day at about 9:00 am. The measured $W_{\text {wet }}$ was used to determine the gravimetric soil $V M C(\%)$ as:

$$
\mathrm{VWC}=\left(\left[W_{w e t}-W_{d r y}\right] \times B D \times 100\right) /\left(W_{d r y}-W_{s}-W_{c}\right)
$$




$$
B D=\left(W_{d r y}-W_{s}-W_{c}\right) / V_{\text {soil }}
$$

\subsection{Statistical Analyses}

The daily gravimetric soil VMC values for each soil type were compared with the sensor readings using linear and non-linear curve-fitting methods. Statistical analyses, including linear regression and analysis of co-variance (ANCOVA) were conducted using the statistical software R, version 3.0.2 [21]. ANCOVA was conducted to test the effect of soil type on the performance of the different soil moisture sensors. This test is normally used to compare two or more regression lines by testing the effect of a categorical factor on a dependent variable while controlling for the effect of a continuous co-variable. The ANCOVA was performed fitting the following model:

$$
\text { Model }<-\operatorname{aov}(y \sim c v * F)
$$

where, $a o v=$ analysis of variance, $y=$ dependent variable (sensor output), $c v=$ covariance variable (gravimetric VWC), and $F$ is the categorical factor variable (soil texture). Linear regression analysis was used to fit the linear response of the EC-5 and VH400 sensors to changes in soil water content. The fitted linear models were of the form:

$$
y=\operatorname{Intercept}+\operatorname{slope}(X)
$$

where, $X=$ independent variable (gravimetric VWC). The curvilinear response of the Watermark 200ss sensors, however, was fitted using Sigma Plot (version 12.5) (Systat Software, Inc., San Jose, CA) using a three-parameter exponential decay model as:

$$
y=y_{o}+a * \exp (-b * X)
$$

where, $y_{o}, a$, and $b$ are empirical constants fitted to the data. In this equation, $y_{o}$ represents the minimum value; $a$ represents the $y$ intercept, and $b$ represents the slope or degree of curvature of the line.

\section{Results and Discussion}

Descriptive statistics for the measured gravimetric VWC for each soil type are shown in Table 2. The Sandy loam soil had the smallest range of VWC between wet and dry (11.26\%) while the Sandy Clay soil had the largest range (22.27\%). The range of VWC was inversely related to the \% Silt in the soil sample while there was poor correlation with either the \% Clay or the \% Sand.

The relationships between the sensor outputs and gravimetric VWC for each soil type are shown in Figures 6-8, for the EC-5, VH400 and Watermak 200ss sensors, respectively. The EC- 5 and $\mathrm{VH} 400$ both responded linearly to changes in VWC for all four soil types. Statistics for the regression equations and parameters are shown in Table 3. Except for the EC-5 sensor in the Sandy Loam soil, which had an $\mathrm{R}^{2}$ of 0.78 , all other linear relationships had an excellent $\mathrm{R}^{2}$ (higher than 0.90 ). The $P$ values in Table 3 indicate the statistical significance of the slope and intercept of the linear relationships. Except for the intercept of the EC-5 
Table 2. Descriptive statistics for measured gravimetric VWC by soil type.

\begin{tabular}{ccccccc}
\hline Soil Texture & $\begin{array}{c}\text { Min. } \\
(\%)\end{array}$ & $\begin{array}{c}\text { Max. } \\
(\%)\end{array}$ & $\begin{array}{c}\text { Midpoint } \\
(\%)\end{array}$ & $\begin{array}{c}\text { Range } \\
(\%)\end{array}$ & $\begin{array}{c}\text { Mean } \\
(\%)\end{array}$ & $\begin{array}{c}\text { Median } \\
(\%)\end{array}$ \\
\hline Loamy Sand & 6.57 & 21.75 & 14.16 & 15.18 & 14.42 & 15.07 \\
Sandy Clay & 7.44 & 29.72 & 18.58 & 22.27 & 19.55 & 21.14 \\
Sandy Clay Loam & 10.28 & 26.86 & 18.57 & 16.57 & 18.55 & 19.23 \\
Sandy Loam & 5.19 & 16.45 & 10.82 & 11.26 & 9.95 & 8.79 \\
\hline
\end{tabular}

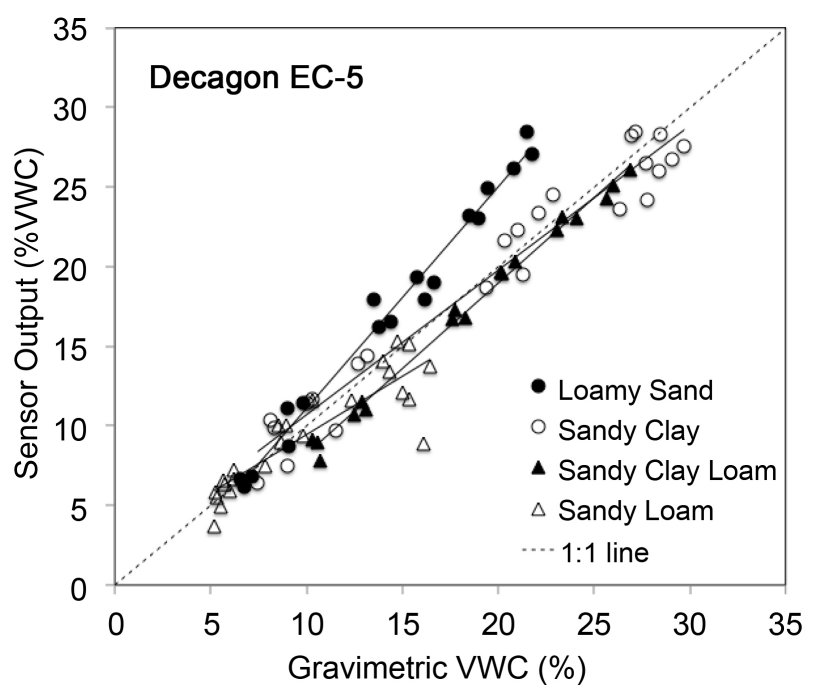

Figure 6. Performance of Decagon EC-5 sensor for four soil types.

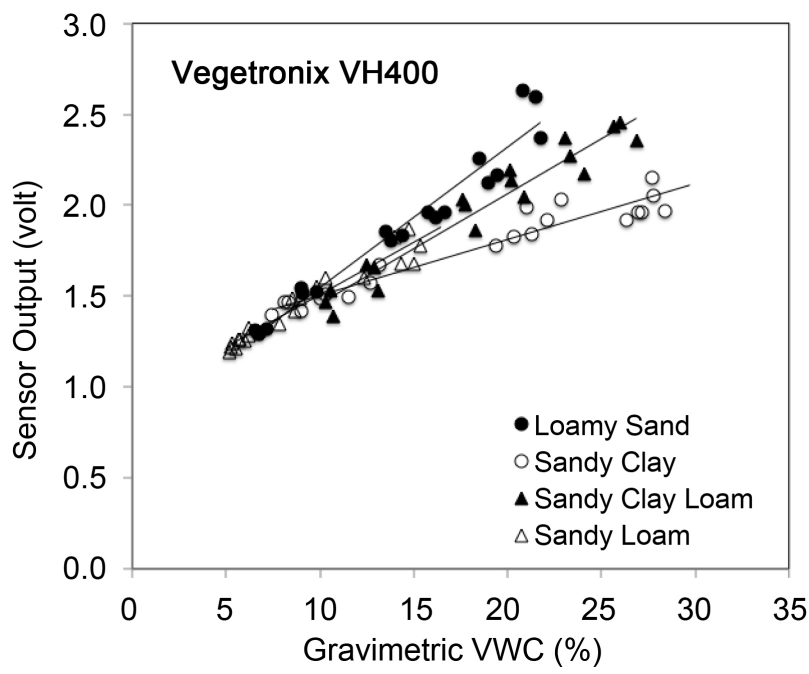

Figure 7. Response of the Vegetronix VH400 sensor for four soil types.

sensor for the Sandy Clay soil, all the slope and intercept were all highly significant for all soil types $(P<0.001)$. These results confirm that the sensors responded well to changes in gravimetric VWC.

The Watermark 200ss, on the other hand, had a non-linear response for all 
soil types, which fitted a three-parameter exponential decay model. Results of model fitting are shown in Table 3. The resulting $\mathrm{R}^{2}$ was excellent for all soil types, ranging from 0.88 to 0.99 . The $\mathrm{P}<0.001$ in Table 3 indicate that the relationships between sensor output and gravimetric VWC was highly significant for all soil types, which is consistent with previous findings [18].

Figures 6-8 however, show that all sensors had distinct relationships for the different soil types. Results of ANCOVA in Table 4 show that gravimetric VWC, Soil Texture and the interaction of gravimetric VWC $\mathrm{x}$ Soil Texture all have a highly significant effect $(P<0.001)$ on the output of the three soil moisture sensors.

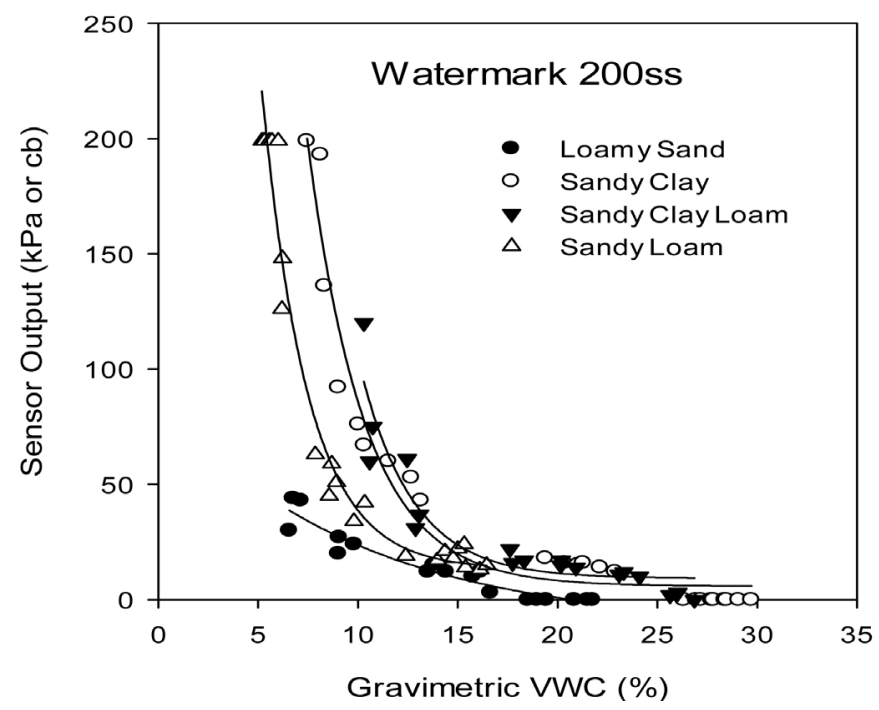

Figure 8. Response of the Watermak 200ss sensor for four soil types.

Table 3. Regression results for the EC-5 sensors.

\begin{tabular}{ccccccc}
\hline \multicolumn{7}{c}{ Decagon EC-5 } \\
\hline Soil Texture & $\mathbf{n}$ & Intercept & Slope & P Intercept & $\boldsymbol{P}$ slope & $\mathbf{R}^{2}$ \\
\hline Loamy Sand & 18 & -2.8068 & 1.39099 & $<0.001$ & $<0.001$ & 0.98 \\
Sandy Clay & 24 & 1.6212 & 0.90766 & NS & $<0.001$ & 0.95 \\
Sandy Clay Loam & 18 & -2.4992 & 1.07310 & $<0.001$ & $<0.001$ & 0.99 \\
Sandy Loam & 24 & 2.1342 & 0.73171 & $<0.05$ & $<0.001$ & 0.78 \\
& & & Vegetronix VH400 & & & \\
Loamy Sand & 18 & 0.7743 & 0.07726 & $<0.001$ & $<0.001$ & 0.94 \\
Sandy Clay & 24 & 1.1966 & 0.03075 & $<0.001$ & $<0.001$ & 0.92 \\
Sandy Clay Loam & 18 & 0.8544 & 0.06042 & $<0.001$ & $<0.001$ & 0.93 \\
Sandy Loam & 24 & 0.9328 & 0.05755 & $<0.001$ & $<0.001$ & 0.93 \\
& & & Watermark 200ss & & & \\
Loamy Sand & 18 & -11.715 & 99.249 & 0.103 & $<0.0001$ & 0.92 \\
Sandy Clay & 24 & 5.868 & 2614.079 & 0.349 & $<0.0001$ & 0.98 \\
Sandy Clay Loam & 18 & 9.306 & 4099.148 & 0.377 & $<0.0001$ & 0.88 \\
Sandy Loam & 24 & 13.281 & 1993.663 & 0.436 & $<0.0001$ & 0.99 \\
\hline
\end{tabular}


Table 4. Results of ANCOVA $[\operatorname{Pr}(>F)]$.

\begin{tabular}{cccc}
\hline Soil Texture & $\begin{array}{c}\text { Decagon } \\
\text { EC-5 }\end{array}$ & $\begin{array}{c}\text { Vegetronix } \\
\text { VH400 }\end{array}$ & Watermark 200ss \\
\hline Gravimetric VWC & $<0.001$ & $<0.001$ & $<0.001$ \\
Soil Texture & $<0.001$ & $<0.001$ & $<0.001$ \\
Gravimetric x Soil Texture & $<0.001$ & $<0.001$ & $<0.001$ \\
\hline
\end{tabular}

Capacitance techniques of measuring soil moisture relies on the fact that the dielectric constant of free water is around 80 , which is much higher than that of a typical dry soil, which is around 1.5 to 4 [22] [23], Therefore, changes in the water content of the soil cause changes in the dielectric constant of the soil-water-air mixture. Although the water content is the main driving factor on the dielectric constant of the soil-water-air mixture, other factors such soil salinity, soil organic matter content, or soil bulk density could also have an impact on the response of soil moisture sensors for different soil types. The soils used in this study, however, were very low in both organic matter $(<1 \%)$ and salinity $(\mathrm{EC}<2$ $\mathrm{dS} / \mathrm{m})$, but they have considerable differences in bulk densities. Therefore, the impact of soil texture on the sensor response could be due to a combination of intrinsic differences in the dielectric constant of the soil particles and to differnces in bulk density among the different soil types.

\section{Conclusion}

We found that the three types of sensors evaluated in this study (Decagon EC-5, Vegetronix VH400, and Watermark 200ss) all had a significant response to changes in soil water content. The EC-5 and VH400 sensors had a linear response, while the Watermark 200ss had a curvilinear response that was explained by an exponential decay function. The response of the three sensors, however, was significantly affected by soil texture, which will significantly affect the trigger point used to initiate irrigation based on the output from these sensors. Therefore, conducting site-specific calibrations is recommended, but since it is unlikely that farmers will perform these calibrations, it is suggested local guidelines on how to use these sensors for local soils need to be made available to farmers.

\section{Acknowledgements}

Technical Contribution No. 6553 of the Clemson University Experiment Station. This material is based upon work supported by USDA/NIFA, under Projects Number SC-1700540, and SC-1700511, and USDA/NRCS under Projects Number 69-3A75-13-88, and 69-4639-14-0010.

\section{Disclaimer}

Mention of trade names does not imply endorsement of products by Clemson University to the exclusion of others that might be available. 


\section{References}

[1] USDA (2010) 2007 Census of Agriculture: Farm and Ranch Irrigation Survey (2008). Vol. 3, Special Studies, Part 1 (AC-07-SS-1). United State Department of Agriculture, National Agricultural Statistics Service, 268 p.

[2] Irmak, S., Burgert, M.J., Yang, H.S., Cassman, K.G., Walters, D.T., Rathje, W.R., Payero, J.O., Grassini, P., Kuzila, M.S., Brunkhorst, K.J., Eisenhauer, D.E., Kranz, W.L., VanDe Walle, B., Rees, J.M., Zoubek, G.L., Shapiro, C.A. and Teichmeier, G.J. (2012) Large-Scale On-Farm Implementation of Soil Moisture-Based Irrigation Management Strategies for Increasing Maize Water Productivity. Transactions of the $A S A B E$, 55, 881-894. https://doi.org/10.13031/2013.41521

[3] Khalilian, A., Han, Y.J. and Farahani, H.J. (2008) Site-Specific Irrigation Management. Eidson and Sawyer, Eds., Proceedings of the 2008 Water Resources Conference, Charleston, 14-15 October 2008.

[4] Miller, G.A. (2012) Sensor Based Irrigation Effects on Root Distribution and Growth of Grafted and Non-Grafted Watermelons. Doctoral Dissertation, Clemson University, Clemson.

[5] Shock, C.C., Barnum, J.M. and Seddigh, M. (1998) Calibration of Watermark Soil Moisture Sensors for Irrigation Management. Proceedings of the International Irrigation Show, San Diego, 1-3 November 1998, 139-146.

[6] Irmak, S. and Haman, D.Z. (2001) Performance of the Watermark Granular Matrix Sensor in Sandy Soils. Applied Engineering in Agriculture, 17, 787-795.

https://doi.org/10.13031/2013.6848

[7] Evett, S.R., Howell, T.A., Steiner, J.L. and Cresap, J.L. (1993) Evapotranspiration by Soil Water Balance Using TDR and Neutron Scattering. In: Allen, R.G. and Neale, C.M.U., Eds., Management of Irrigation and Drainage Systems, Integrated Perspectives, American Society of Civil Engineers, New York, 914-921.

[8] Evett, S.R. and Steiner, J.L. (1995) Precision of Neutron Scattering and Capacitance Type Soil Water Content Gauges from Field Calibration. Soil Science Society of American Journal, 59, 961-968. https://doi.org/10.2136/sssaj1995.03615995005900040001x

[9] Payero, J.O., Tarkalson, D.D. and Irmak, S. (2006) Use of Time Domain Reflectometry for Continuous Monitoring of Nitrate-Nitrogen in Soil and Water. Applied Engineering in Agriculture, 22, 689-700. https://doi.org/10.13031/2013.22002

[10] Young, M.H., Wierenga, P.J. and Mancino, C.F. (1997) Monitoring Near-Surface Soil Water Storage in Turfgrass Using Time Domain Reflectometry and Weighing Lysimetry. Soil Science Society of American Journal, 61, 1138-1146. https://doi.org/10.2136/sssaj1997.03615995006100040021x

[11] Chandler, D.G., Seyfried, M.S., Murdock, M. and McNamara, J.P. (2004) Field Calibration of Water Content Reflectometers. Soil Science Society of America Journal, 68, 1501-1507. https://doi.org/10.2136/sssaj2004.1501

[12] Baumhardt, R.L., Lascano, R.J. and Evett, S.R. (2000) Soil Material, Temperature, and Salinity Effects on Calibration of Multisensor Capacitance Probes. Soil Science Society of American Journal, 64, 1940-1946.

https://doi.org/10.2136/sssaj2000.6461940x

[13] Evett, S.R., Tolk, J.A. and Howell, T.A. (2006) Soil Profile Water Content Determination: Sensor Accuracy, Axial Response, Calibration, Temperature Dependence, and Precision. Vadose Zone Journal, 5, 894-907.

https://doi.org/10.2136/vzj2005.0149

[14] Decagon Devices, Inc. (2014) EC-5 Soil Moisture Sensor: Operator's Manual. Deca- 
gon Devices, Inc., Pullman, 19 p.

[15] Vegetronix (2008) VH400 Soil Moisture Sensor Probes. http://www.vegetronix.com/Products/VH400/

[16] Irrometer (No Date) WATERMARK Soil Moisture Sensor-Model 200SS. http://www.irrometer.com/pdf/sensors/403\%20WATERMARK\%20Sensor-WEB.pdf

[17] Irmak, S., Payero, J.O., Eisenhauer, D., Kranz, W.L., Martin, D.L., Zoubek, G., Rees, J.M., Christiansen, A. and Leininger, D. (2006) Watermark Granular Matrix Sensors to Measure Soil Matric Potential for Irrigation Management. Extension Circular EC783, University of Nebraska-Lincoln Cooperative Extension, 7 p.

[18] Irmak, S., Payero, J.O., VanDeWalle, B., Rees, J. and Zoubek, G. (2014) Principles and Operational Characteristics of Watermark Granular Matrix Sensor to Measure Soil Water Status and Its Practical Applications for Irrigation Management in Various Soil Textures. Extension Circular EC783. University of Nebraska-Lincoln Extension, $14 \mathrm{p}$.

[19] Gee, G.W. and Bauder, J.W. (1979) Particle Size Analysis by Hydrometer: A Simplified Method for Routine Textural Analysis and a Sensitivity Test of Measurement Parameters. Soil Science Society of America Journal, 43, 1004-1007. https://doi.org/10.2136/sssaj1979.03615995004300050038x

[20] Saxton, K.E., Rawls, W., Romberger, J.S. and Papendick, R.I. (1986) Estimating Generalized Soil-Water Characteristics from Texture. Soil Science Society of America Journal, 50, 1031-1036. https://doi.org/10.2136/sssaj1986.03615995005000040039x

[21] R Core Team (2013) R: A Language and Environment for Statistical Computing. R Foundation for Statistical Computing, Vienna. http://www.R-project.org/

[22] Dean, T.J., Bell, J.P. and Baty, A.J.B. (1987) Soil Moisture Measurement by an Improved Capacitance Technique, Part I. Sensor Design and Performance. Journal of Hydrology, 93, 67-78. https://doi.org/10.1016/0022-1694(87)90194-6

[23] Atkins, R.T., Pangburn, T., Bates, R.E. and Brockett, B.E. (1998) Soil Moisture Determinations Using Capacitance Probe Methodology. Special Report 98-2, US Army Corps of Engineers, Cold Region Research \& Engineering Laboratory, 49.

\section{Submit or recommend next manuscript to SCIRP and we will provide best} service for you:

Accepting pre-submission inquiries through Email, Facebook, LinkedIn, Twitter, etc. A wide selection of journals (inclusive of 9 subjects, more than 200 journals)

Providing 24-hour high-quality service

User-friendly online submission system

Fair and swift peer-review system

Efficient typesetting and proofreading procedure

Display of the result of downloads and visits, as well as the number of cited articles

Maximum dissemination of your research work

Submit your manuscript at: http://papersubmission.scirp.org/

Or contact jwarp@scirp.org 